\title{
pTDN1, A Catabolic Plasmid Involved in Aromatic Amine Catabolism in Pseudomonas putida mt-2
}

\author{
By NICHOLAS C. MCCLURE ${ }^{*}$ AND W. A. VENABLES ${ }^{2}$ \\ Department of Applied Biology, UWIST, Cathays Park, PO Box 13, Cardiff CFI 3XF, UK \\ ${ }^{2}$ Department of Microbiology, University College, Newport Road, Cardiff CF2 ITA, UK
}

(Received 30 March 1987)

\begin{abstract}
The ability of Pseudomonas putida mt-2 strain UCC2 to grow with aniline, $m$ - and $p$-toluidine and $m$-toluate (the $\mathrm{Tdn}^{+}$phenotype) is plasmid encoded. Strain UCC2 contains two plasmids of which pUCC2 is a deleted derivative of the TOL plasmid pWW0 (Worsey \& Williams, 1975) and can be lost from the strain with no effect on the $\mathrm{Tdn}^{+}$phenotype. The second plasmid in strain UCC2, pTDN1, harbours genes involved in the $\mathrm{Tdn}^{+}$phenotype and is conjugative. The catechol 2,3-dioxygenase (C23O) structural gene resident on pTDN1 has been cloned into the broad host range vector pK T231. The relative specific activity towards substituted catechols of C23O expressed in the cloned fragment in Escherichia coli is similar to that expressed in P. putida strain UCC2.
\end{abstract}

\section{INTRODUCTION}

Anilines and ring-substituted anilines are major products of herbicide metabolism in the soil (Cripps \& Roberts, 1978) and, as potential environmental pollutants, their biodegradation is of considerable interest. Several bacteria capable of utilizing anilines or toluidines (methylanilines) as sole sources of carbon and energy have been isolated (Aoki et al., 1983, 1984; Kaminski et al., 1983; Helm \& Reber, 1979; Appel et al., 1984; Raabe et al., 1984). Preliminary evidence for plasmid involvement in aromatic amine catabolism has been shown for Pseudomonas sp. strain CIT1 (Anson \& Mackinnon, 1984) and Pseudomonas strain JLl (Latorre et al., 1984).

Recently, a derivative of Pseudomonas putida $\mathrm{mt}-2$ ( $\mathrm{pWW} 0$ ) has been described that is capable of utilizing aniline, and $m$ - and $p$-toluidine as sole sources of carbon and nitrogen (McClure \& Venables, 1986). This strain of $P$. putida $\mathrm{mt}-2$, designated strain UCC2, metabolized these substrates by oxidative deamination followed by dissimilation via an inducible meta-cleavage pathway. Strain UCC2 was shown to contain two plasmids, a deleted derivative of the TOL plasmid pWW0, pUCC2, and a novel plasmid designated pTDN1. Strain UCC2 was also found to lose the $\mathrm{Tdn}^{+}$phenotype, readily and irreversibly, during subculture on benzoate or other nonselective carbon sources. In all such $\mathrm{Tdn}^{-}$derivatives, pUCC2 appeared unaltered, whereas pTDN 1 had invariably been lost or undergone deletion. It was assumed therefore, that pTDN 1 encoded the $\mathrm{Tdn}^{+}$phenotype, and that pUCC2 made no contribution to it. In the present study, we validate this assumption by the isolation of derivatives of strain UCC2 in which pUCC2 has been lost and pTDN1 retained, and also by cloning part of the Tdn pathway.

\section{METHODS}

Bacterial strains. The bacterial strains used in this study are listed in Table 1. Batch cultures for assay of catechol 2,3-dioxygenase (C23O) were prepared as previously described (McClure \& Venables, 1986).

Preparation of cell extracts. Crude extracts for $\mathrm{C} 23 \mathrm{O}$ assay were prepared by resuspending cell pellets in $0 \cdot 1 \mathrm{M}$ potassium phosphate buffer $\mathrm{pH} 7.5$ with $10 \%(\mathrm{v} / \mathrm{v})$ acetone. The samples were sonicated for five periods of $40 \mathrm{~s}$ at

Abbreviation: C23O, catechol 2,3-dioxygenase (EC 1.13.11.2). 
Table 1. Bacterial strains and plasmids

\begin{tabular}{|c|c|c|c|}
\hline Strain & Plasmid & Genotype/phenotype & Reference \\
\hline $\begin{array}{l}\text { P. aeruginosa PU21 } \\
\text { E. coli SK } 1592\end{array}$ & $\begin{array}{c}\text { R2 } \\
-\end{array}$ & $\begin{array}{l}\mathrm{Ilv}^{-} \mathrm{Leu}^{-} \mathrm{Cb} \mathrm{Sm} \mathrm{Su} \\
\text { end } A \text { gal hsdR4 } \\
\text { hsd } M^{+} \text {sbcB15 thi } \mathrm{T} 1^{\mathrm{r}}\end{array}$ & $\begin{array}{l}\text { Bayley et al. (1979) } \\
\text { Kushner (1978) }\end{array}$ \\
\hline $\begin{array}{l}\text { P. putida mt-2 } \\
\text { PaW8 } \\
\text { KT2442 } \\
\text { UCC2 } \\
\text { UCC2-2 }\end{array}$ & $\begin{array}{c}\text { pWW0-8 } \\
- \\
\text { pTDN1, pUCC2 } \\
\text { pTDN1 }\end{array}$ & $\begin{array}{l}\mathrm{Mxy}^{-} \mathrm{Mtol}^{-} \\
h s d R I h s d M^{+} \mathrm{Rif} \\
\mathrm{Tdn}+, \mathrm{Mxy}^{-} \\
\mathrm{Tdn}^{+}, \mathrm{Mxy}^{-}\end{array}$ & $\begin{array}{l}\text { Williams \& Murray (1974) } \\
\text { Franklin et al. (1981) } \\
\text { McClure \& Venables (1986) } \\
\text { This study }\end{array}$ \\
\hline
\end{tabular}

$0^{\circ} \mathrm{C}$ in an MSE Soniprep 50. After removal of cell debris by centrifugation at $100000 \mathrm{~g}$ for $60 \mathrm{~min}$ at $4{ }^{\circ} \mathrm{C}$, the supernatant was used for assay.

Enzyme assay. C23O was assayed as described by Sala-Trepat \& Evans (1971), using catechol, 3-methylcatechol and 4-methylcatechol as assay substrates.

Conjugation. Plate filter matings were done as described by McClure \& Venables (1986).

Plasmid isolation. Plasmid DNA was isolated by the method of Wheatcroft \& Williams (1981) for large plasmids, and by the 'cleared lysate' method (Guerry et al., 1974) for vector DNA. Rapid screening of plasmid DNA in transformants was done using the method of Holmes \& Quigley (1981). Restriction endonuclease digestion and gel electrophoresis were done as previously described (McClure \& Venables, 1986).

Cloning of the $\mathrm{C} 23 \mathrm{O}$ gene. The gene encoding the $\mathrm{C} 23 \mathrm{O}$ enzyme in strain UCC 2 was cloned following ligation and transformation by standard procedures and as described (McClure, 1986).

\section{RESULTS}

Elimination of pUCC2 from strain UCC 2 was accomplished by introduction of the resistance plasmid R2 which is incompatible with pWW0 (Bayley et al., 1979) and therefore also with pUCC2. Plasmid R2 was transferred from $P$. aeruginosa PU21 to strain UCC2 and transconjugants selected on aniline minimal agar plates containing streptomycin $\left(1 \mathrm{mg} \mathrm{ml}^{-1}\right)$. One such transconjugant was subjected to growth at elevated temperature $\left(37^{\circ} \mathrm{C}\right)$ or in the presence of acridine orange or mitomycin C (up to $30 \mu \mathrm{g} \mathrm{ml}^{-1}$ ) in an attempt to cure this strain of R2. Growth in aniline minimal medium at elevated temperature $\left(37^{\circ} \mathrm{C}\right)$ was the only treatment which resulted in detectable loss of streptomycin resistance (encoded by $\mathrm{R} 2$ ), at a level of $1 \%$ after 50 generations.

Plasmid DNA was prepared from one of the $\mathrm{Tdn}^{+} \mathrm{Sm}^{\mathrm{s}}$ derivatives isolated above (strain UCC2-2) and subjected to endonuclease digestion with EcoRI, Hindlll, and XhoI. The restriction profiles obtained were compared to those of plasmid DNA isolated from strain UCC2 and pWW0-8, which is identical to pUCC2 (Fig. 1). The restriction profiles of plasmid DNA from strain UCC2-2 (tracks 4, 7 and 10) are consistent with the conclusion that this strain carries a single plasmid, pTDN1. The restriction profiles of plasmid DNA from strain UCC2 (tracks 3,6 and 9) represent fragments arising from both pTDN1 and pUCC.2.

\section{Transfer of the $T d n^{+}$phenotype from strain UCC2-2}

The $\mathrm{Tdn}^{+}$phenotype was transferable from strain UCC2-2, the derivative containing only pTDN1, to $P$. putida KT2442 at a similar frequency to that from the parent strain UCC2 $\left(>1 \times 10^{-4}\right.$ transconjugants per donor cell). One such transconjugant contained a single plasmid indistinguishable from pTDN 1 on the basis of endonuclease restriction profile (data not shown). Therefore, pTDN 1 is a conjugative plasmid capable of mediating its own transfer in the presence or absence of pUCC2. 


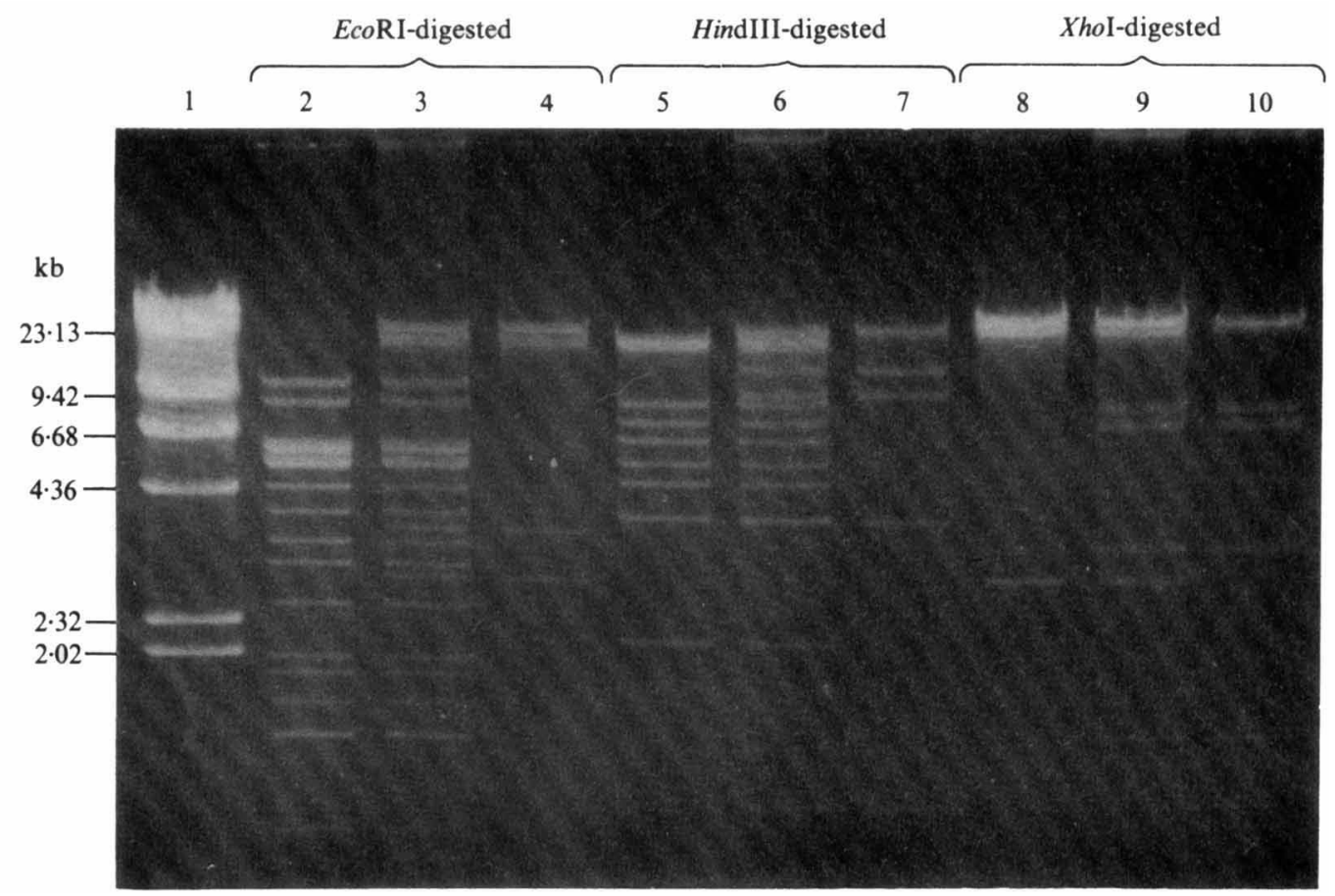

Fig. 1. Restriction digests of plasmid DNA from UCC2, UCC2-2 and pWW0-8. Lane 1, $\lambda$ Hind III standard ; lanes 2, 5 and 8, pWW0-8: lanes 3,6 and 9, UCC2 plasmid DNA; lanes 4, 7 and 10, UCC2-2 plasmid DNA.

Table 2. Relative C23O activity in cell free extracts of E. coli SK1592(pNCMI) and strain UCC2

$\begin{array}{llcl}\begin{array}{l}\text { Assay } \\ \text { substrate ... }\end{array} & \overbrace{\text { Catechol }} & \text { 3-Methylcatechol } & \text { 4-Methylcatechol } \\ & & 200 & 41 \\ 100(1770) & 197 & 43 \\ 100(1830) & 220 & 44 \\ 100(1450) & 180 & 40 \\ & & \end{array}$

- Percentage of activity with catechol, specific activity given in parentheses as milliunits (mg protein) ${ }^{-1}$. One unit of activity is the amount of enzyme required to convert $1 \mu \mathrm{mol}$ substrate $\mathrm{min}^{-1}$. Specific activities given are the mean of at least three independent determinations.

\section{Cloning of the C23O gene from strain UCC2}

Plasmid DNA isolated from strain UCC2 was digested with $\mathrm{XhoI}$ and ligated to the broad host range vector pK T231 (Bagdasarian et al., 1981) cleaved with the same enzyme. Following ligation overnight, the ligation mix was used to transform Escherichia coli SK 1592 and transformants selected were sprayed with $100 \mathrm{~mm}$-catechol to detect colonies expressing C23O activity. Such colonies immediately turn yellow due to the conversion of catechol to 2hydroxymuconic semialdehyde. One such colony was purified and was shown to contain an insert into the kanamycin resistance gene of the vector, corresponding to the $7.6 \mathrm{~kb} \mathrm{Xhol}$ fragment of pTDN1. This plasmid is designated pNCM1.

The specific enzyme activity of $\mathrm{C} 23 \mathrm{O}$ was estimated in cell free extracts prepared from batch cultures of $E$. coli SK 1592 (pNCMI) grown with acetate, acetate $+m$-toluate, and acetate $+p$ toluidine as carbon sources (Table 2). High C23O activity was observed in cell free extracts of $E$. 
coli SK1592(pNCM1) irrespective of the growth substrate. This suggests that transcription occurred from the active kanamycin resistance gene promoter of pKT231, as Pseudomonas promoters have been shown to function to a negligible extent in $E$. coli (Franklin et al., 1981). The ratio of activity of $\mathrm{C} 23 \mathrm{O}$ of $E$. coli SK1592(pNCM1) towards catechol, 4-methylcatechol and 3-inethylcatechol is similar to that observed with strain UCC2, and differs from the C23O specified by the TOL plasmid pWWO (McClure \& Venables, 1986).

\section{DISCUSSION}

In this study we provide conclusive evidence that a novel plasmid pTDN 1 is involved in the ability of $P$. putida mt-2 strain UCC2 to grow on aniline, $m$ - and $p$-toluidine and $m$-toluate. The gene encoding the meta-cleavage enzyme $\mathrm{C} 23 \mathrm{O}$ is situated on a $7.6 \mathrm{~kb}$ Xhol fragment of pTDN1. The relative activity of $\mathrm{C} 23 \mathrm{O}$ towards catechol and 3- and 4-methylcatechol in $E$. coli SK 1592(pNCM1) is similar to that of the enzyme in strain UCC2. It is also interesting to note the similarity in substrate specificity to the C23O II enzyme encoded on pWW15, which has been shown to contain two non-homologous C23O genes (Keil et al., 1985).

The majority of $\mathrm{Tdn}^{-}$derivatives of strain UCC2 examined have undergone deletion from pTDN1 rather than loss of the complete plasmid (McClure, 1986; unpublished results). The high frequency with which these events occur suggests that pTDN1 contains structural features which result in ready deletion of specific, though not unique, segments of pTDN1. Both pRA500 of $P$. putida and the TOL plasmid pWW20 of $P$. putida MT20 undergo a variety of non-specific deletions giving rise to cured derivatives (Jain et al., 1984; Pickup \& Williams, 1982).

The isolation of strain UCC 2-2 containing only pTDN 1 will greatly facilitate further detailed investigation and characterization of aromatic amine catabolism in $P$. putida $\mathrm{mt}-2$. The origin of pTDN1 is presently under investigation. Loss of pUCC2 has no effect on the ability of strain UCC2 to grow with aniline, $m$ - or $p$-toluidine or $m$-toluate and therefore does not appear to play a role in the catabolism of these substrates.

We are grateful to Professor P. A. Williams for supplying $P$. aeruginosa PU21(R2) and $P$. putida PaW8(pWW0-8).

\section{REFERENCES}

Anson, J. G. \& Mackinnon, G. (1984). Novel Pseudomonas plasmid involved in aniline degradation. Applied and Environmental Microbiology 48, 868-869.

AOKi, K., Shinke, R. \& Nishira, H. (1983). Metabolism of aniline by Rhodococcus erythropolis AN-13. Agricultural and Biological Chemistry 47, 1611-1616.

Aoki, K., Ohtsuka, K., Shinke, R. \& Nishira, H. (1984). Rapid biodegradation of aniline by Frateuria species ANA-18 and its aniline metabolism. Agricultural and Biological Chemistry 48, 865-872.

APPEL, M., RAABE, T. \& Lingens, F. (1984). Degradation of o-toluidine by Rhodococcus rhodochrous. FEMS Microbiology Letters 24, 123-126.

Bagdasarian, M., LuRz, R., Rueckert, B., FrankLiN, F. C. H., BAgdasarian, M. M., Frey, J. \& TIMmis, K. N. (1981). Specific-purpose plasmid cloning vectors II. Broad host range, high copy number, RSF 1010-derived vectors, and a hostvector system for gene cloning in Pseudomonas. Gene 16, 237-247.

Bayley, S. A., Duggleby, C. J., Worsey, M. J., Williams, P. A., Hardy, K. G. \& Broda, P. (1977). Two modes of loss of the TOL function from Pseudomonas putida mt-2. Molecular and General Genetics 154, 203-204.

Bayley, S. A., Morris, D. W. \& Broda, P. (1979). The relationship of degradative and resistance plasmids of Pseudomonas belonging to the same incompatibility group. Nature, London $280,338-339$.

CRIPPS, R. E. \& Roberts, T. R. (1978). Microbial degradation of herbicides. In Pesticide Microbiology, pp. 669-730. Edited by J. R. Hill \& S. J. L. Wright. London: Academic Press.

Franklin, F. C. H., Bagdasarian, M., Bagdasarian, M. M. \& TIMmis, K. N. (1981). Molecular and functional analysis of the TOL plasmid $\mathrm{pWW} 0$ from Pseudomonas putida and cloning of genes for the entire regulated, aromatic ring meta-cleavage pathway. Proceedings of the National Academy of Sciences of the United States of America 78, 7458-7462.

Guerry, P., Leblanc, D. J. \& Falkow, S. (1973). General method for the isolation of plasmid deoxyribonucleic acid. Journal of Bacteriology 116, 1064 1066.

HeLm, V. \& Reber, H. (1979). Investigation of the regulation of aniline utilisation in Pseudomonas multivorans strain AN1. European Journal of Applied Microbiology and Biotechnology 7, 191-199.

Holmes, D. S. \& QuigleY, M. (1981). A rapid boiling method for the preparation of bacterial plasmids. Analytical Biochemistry 114, 193-197.

JAIN, R. K., BaYly, R. C. \& Skurray, R. A. (1984). Characterization and physical analysis of a 3,5xylenol degradative plasmid in Pseudomonas putida. Journal of General Microbiology 130, 3019--3028. 
Kaminski, U., Janke, D., Prauser, H. \& Fritche W. (1983). Degradation of aniline and monochloroaniline by Rhodococcus sp. AN 117 and a pseudomonad: a comparative study. Zeitschrift für allgemeine Mikrobiologie 23, 235-246.

KUSHNER, S. R. (1978). An improved method for transformation of Escherichia coli with ColEl derived plasmids. In Genetic Engineering, pp. 17-23. Edited by H. B. Boyer \& S. Nicoza. Amsterdam: Elsevier.

LATORRE, J., Reineke, W. \& KnACKMUSS, H. J. (1984). Microbial metabolism of chloroanilines: enhanced evolution by natural genetic exchange. Archives of Microbiology 140, 159-165.

MCCLURE, N. C. (1986). Genetic and biochemical studies of aromatic amine catabolism by Pseudomonas species. PhD thesis, University of Wales.

MCClure, N. C. \& Venables W. A. (1986). Adaptation of Pseudomonas putida mt-2 to growth on aromatic amines. Journal of General Microbiology 132, 2209-2218.
Pickup, R. W. \& Williams, P. A. (1982). Spontaneous deletions in the TOL plasmid pWW20 which give rise to the B3 regulatory mutants of Pseudomonas putida MT20. Journal of General Microbiology 128, $1385-1390$.

RaABe, T., APPel, M. \& Lingens, F. (1984). Degradation of $p$-toluidine by Pseudomonas testosteronii. FEMS Microbiology Letters 25, 61-64.

Sala-Trepat, J. M. \& Evans, W. C. (1971). The metacleavage of catechol by Azotobacter species: the 4oxalocrotonate pathway. European Journal of Biochemistry 20, 400-413.

Williams, P. A. \& Murray, K. (1974). Metabolism of benzoate and the methylbenzoates by Pseudomonas putida (arvilla) mt-2: evidence for the existence of a TOL plasmid. Journal of Bacteriology 120, 416-423.

Worsey, M. J. \& Williams, P. A. (1975). Metabolism of toluene and the xylenes by Pseudomonas putida (arvilla) $\mathrm{mt}-2$ : evidence for a new function of the TOL plasmid. Journal of Bacteriology 124, 7-13. 